\title{
Impact Strength of Denture Base and Reline Acrylic Resins Subjected to Long-Term Water Immersion
}

\author{
Amanda Fucci WADY \\ Ana Lucia MACHADO \\ Carlos Eduardo VERGANI \\ Ana Cláudia PAVARINA \\ Eunice Teresinha GIAMPAOLO
}

Department of Dental Materials and Prosthodontics, Araraquara Dental School, UNESP - Univ. Estadual Paulista, Araraquara, SP, Brazil

\begin{abstract}
Water may influence the mechanical properties of the acrylic resins. Thus, the effect of water storage on the impact strength (IS) of one denture base (Lucitone 550 - L) and four reline resins (Tokuyama Rebase II - T; UfiGel Hard - U; Kooliner - K; New Truliner - NT) was evaluated. Bars of L were made $(60 \times 6 \times 2 \mathrm{~mm})$ and relined $(2 \mathrm{~mm})$ with T, U, K, NT and L. Intact specimens of each material $(60$ x 6 x $4 \mathrm{~mm}$ ) were also fabricated for comparative purposes. Specimens were submitted to Charpy impact tests without water storage (control) and after immersion in water for 7, 90 and 180 days. Data $\left(\mathrm{kJ} / \mathrm{m}^{2}\right)$ analyzed by two-way ANOVA and Tukey's test ( $\left.\mathrm{p}=0.05\right)$ revealed that after 90 days, $\mathrm{U}$ exhibited an increase in the IS (0.93) compared to 7 days $(0.58) . \mathrm{K}(1.48)$ and $\mathrm{L} / \mathrm{K}(7.21)$ exhibited a decrease at the 7-day period (1.01 and 3.23, respectively). NT (0.60) showed an increase in the IS after 180 days (1.52), whereas L/ NT (7.70) showed a decrease (3.17). Water immersion improved the IS of U and NT, and decreased the IS of K, L/K, and L/NT. Water may affect differently the IS of acrylic resins and, consequently, the resistance to fracture of relined denture bases.
\end{abstract}

Key Words: acrylic resins, relining, removable dentures, impact strength, water immersion.

\section{INTRODUCTION}

A frequent problem that occurs with removable dentures is fracture, which may be due to accidental dropping, repeated masticatory forces, and areas of stress concentrations around frenal notches (1). For this reason, the impact strength (IS) of polymers used for the production of denture bases has been investigated (2-5), with focus on the incorporation of different types of reinforcements $(1,6)$. Adequate IS of the hard chairside reline resins, which have been often used to improve the retention and stability of removable prostheses, is also important (7). Both powder and liquid composition of reline resins differ considerably from that of the poly(methyl methacrylate)/methyl methacrylate acrylic resins (8). In addition, the residual monomer content in some autopolymerizing reline resins is higher than in heat-polymerizing denture base acrylic resins (9). Variations in composition and residual monomer levels influence the mechanical properties of polymers $(8,10,11)$, and lower flexural strength of autopolymerizing reline resins, compared to heatpolymerized acrylic resins, has been reported (8). The IS of reline resins may also be affected by these factors.

The relined denture base is composed of two different materials with an interface between them. In this situation, the strength of relined specimens depends on the bulk strength of both the denture base and reline materials (12). The degree of interfacial adhesion also plays a role (7). The chemical composition of the bonding agents and relining materials affect the depth of the swollen layers (13) of the denture base polymers and the strength of adhesion $(14,15)$. A weak bond may result in adhesive failures at the interface between the two materials under relatively low stresses. Hence, the IS of the reline resins and their ability to bond to the denture base resins may influence the impact strength of the relined dentures (7).

Also important is the fact that during clinical use the polymers are either immersed in saliva or soaked in

Correspondence: Profa. Dra. Ana Lucia Machado, Departamento de Materiais Odontológicos e Prótese, Faculdade de Odontologia de Araraquara, UNESP, Rua Humaitá, 1680, 14801-903 Araraquara, SP, Brasil. Tel: +55-16-3301-6410. Fax: +55-16-3301-6406. e-mail: cucci@foar.unesp.br 
denture cleansers or water. Aging in water or aqueous solutions has been reported to decrease the mechanical properties of the acrylic resins (12), and the bond strength between denture base and reline resins (16).

The aim of this study was to evaluate the effect of long-term water storage on the IS of 1 denture base acrylic resin relined with 4 hard chair-side reline resins. The effect of water storage on the IS of bulk specimens of the denture base acrylic resin and each autopolymerizing reline material was also evaluated for the purpose of comparison. The working hypothesis was that water storage would not have a significant effect on the IS of the denture base resin and the reline materials.

\section{MATERIAL AND METHODS}

One heat-polymerized denture base acrylic resin and four autopolymerizing reline resins were selected for this study (Table 1). Initially, rectangular bars $(60 \mathrm{x}$ $6 \times 2 \mathrm{~mm}$ ) from L material were prepared. The acrylic resin was proportioned and the mixture in the dough stage was inserted into the mold in a dental flask and packed. Molds were prepared by investing silicone patterns (ZetaPlus putty; Zhermack, Badia Polesine, Rovigo, Italy), placed between 2 glass slides, in type IV stone (Troquel Quatro; Polidental Manufacturing and Trade Ltd., São Paulo, SP, Brazil). The denture base acrylic resin was polymerized in a thermostatically controlled water bath (Termotron P-100; Termotron,
Piracicaba, SP, Brazil) according to the manufacturer's recommendations (Table 1 ). After polymerization, the flasks were bench cooled at room temperature for $30 \mathrm{~min}$ and then placed for 15 min under running water before opening, following the manufacturer's instructions. Thereafter, the L rectangular bars were removed from the flasks, the edges were finished with 400-grit silicon carbide paper, and the accuracy of the dimensions was verified at 3 locations for each dimension. A tolerance of $\pm 0.03 \mathrm{~mm}$ was accepted. The $\mathrm{L}$ rectangular bars were stored in distilled water at $37 \pm 1^{\circ} \mathrm{C}$ for $50 \pm 2 \mathrm{~h}$ before relining (17). After water storage, the denture base resin surfaces to be bonded with the reline materials were ground wet in an automatic grinding machine (Metaserv 2000 model 95-2829; Buehler UK Ltd., Coventry, England) using silicon carbide paper (240grit) $(7,16)$. The surfaces were brushed with liquid detergent for $20 \mathrm{~s}$, rinsed with distilled water, and dried with absorbent paper. Before the L rectangular bars are relined with the autopolymerizing materials NT, T and $\mathrm{U}$, the bond surfaces were treated with the bonding agents recommended by the manufacturers, whereas for the reline resin $\mathrm{K}$, methyl methacrylate monomer was applied for $180 \mathrm{~s}$ (18).

The relined specimens were fabricated using a stainless steel mold with a cavity of $60 \times 6 \times 4 \mathrm{~mm}$. The $L$ rectangular bars were placed into the cavity and the reline resins were inserted to fill the remainder of the mold. Manufacturers' instructions for mixing and

Table 1. Materials used in this study.

\begin{tabular}{|c|c|c|c|c|c|c|c|}
\hline \multirow{2}{*}{ Material } & \multirow{2}{*}{ Code } & \multirow{2}{*}{ Batch \# } & \multirow{2}{*}{ Manufacturers } & \multicolumn{2}{|c|}{ Composition } & \multirow{2}{*}{$\begin{array}{l}\text { Powder/Liquid } \\
\text { ratio }(\mathrm{g} / \mathrm{mL})\end{array}$} & \multirow{2}{*}{$\begin{array}{l}\text { Polymerization } \\
\text { cycles }\end{array}$} \\
\hline & & & & Powder & Liquid & & \\
\hline Kooliner & $\mathrm{K}$ & 0508187 & $\begin{array}{l}\text { GC America Inc, } \\
\text { Alsip, IL, USA }\end{array}$ & PEMA & IBMA & $2.1 / 1.0$ & $\begin{array}{l}10 \text { min at room } \\
\text { temperature }\end{array}$ \\
\hline New Truliner & NT & 0310528 & $\begin{array}{l}\text { The Bosworth Co., } \\
\text { Skokie, IL, USA }\end{array}$ & PEMA & $\begin{array}{l}\text { IBMA } \\
\text { DBP }\end{array}$ & $1.34 / 1.0$ & $\begin{array}{l}20 \text { min at room } \\
\text { temperature }\end{array}$ \\
\hline $\begin{array}{l}\text { Tokuyama } \\
\text { Rebase II }\end{array}$ & $\mathrm{T}$ & UF64145 & $\begin{array}{l}\text { Tokuyama Dental Corp., } \\
\text { Tokyo, Japan }\end{array}$ & PEMA & $\begin{array}{l}\text { AAE } \\
\text { ND }\end{array}$ & $2.4 / 1.0$ & $\begin{array}{l}5.5 \text { min at room } \\
\text { temperature }\end{array}$ \\
\hline UfiGel Hard & $\mathrm{U}$ & 631742 & Voco, Cuxhaven, Germany & PEMA & HDMA & $2.12 / 1.2$ & $\begin{array}{l}7 \text { min at room } \\
\text { temperature }\end{array}$ \\
\hline Lucitone 550 & $\mathrm{~L}$ & $\begin{array}{l}\text { P-303758 } \\
\text { L-213457 }\end{array}$ & $\begin{array}{l}\text { Dentsply Ind. e Com. Ltda., } \\
\text { Petrópolis, RJ, Brazil }\end{array}$ & PMMA & $\begin{array}{c}\text { MMA } \\
\text { EDGMA }\end{array}$ & $2.1 / 1.0$ & $\begin{array}{l}90 \text { min at } 73^{\circ} \mathrm{C} ; \\
30 \text { min at } 100^{\circ} \mathrm{C}\end{array}$ \\
\hline
\end{tabular}

PEMA = poly(ethyl methacrylate); PMMA = poly(methyl methacrylate); IBMA= isobutyl methacrylate; DBP = di-n-butyl phthalate; $\mathrm{AAE}=2$-(acetoacetoxy) ethyl methacrylate; $\mathrm{ND}=1$,9-nonanediol dimethacrylate; $\mathrm{HDMA}=1$,6-hexanediol dimethacrylate; $\mathrm{MMA}=$ methyl methacrylate; EDGMA = ethylene glycol dimethacrylate. 
processing were followed of each reline material (Table 1). An acetate sheet and a glass plate were placed over the reline material, and load (500 kgf) was applied until polymerization was complete. The edges of the specimens were finished and the accuracy of the dimensions (width and thickness) was checked with a caliper (Mitutoyo Sul Americana, Suzano, SP, Brazil) at 3 locations of each dimension to within $0.03 \mathrm{~mm}$ tolerance (7).

To evaluate the IS of specimens made following laboratory reline procedures, $\mathrm{L}$ rectangular bars were relined with the same material. Initially, silicone patterns $(60 \times 6 \times 4 \mathrm{~mm})$ were obtained, placed between 2 glass slides, and then flasked to create molds for packing the $\mathrm{L}-\mathrm{L}$ specimens. The $\mathrm{L}$ rectangular bars $(2.0 \mathrm{~mm})$ were then adapted in the lower portion of the stone mold and the remaining $2.0 \mathrm{~mm}$ was filled with $\mathrm{L}$ acrylic resin dough. Processing, finishing and verification of the accuracy of the specimens were performed as described.

Table 2. Impact strength mean values $\left(\mathrm{kJ} / \mathrm{m}^{2}\right)$ and standard deviations of acrylic resins and groups evaluated.

\begin{tabular}{|c|c|c|c|c|}
\hline \multirow{2}{*}{ Materials } & \multicolumn{4}{|c|}{ Groups } \\
\hline & $\mathrm{C}$ & Wim7d & Wim90d & Wim180d \\
\hline $\mathrm{L}$ & $1.63 \pm 0.14^{\mathrm{Ba}}$ & $1.52 \pm 0.12^{\mathrm{Ca}}$ & $1.62 \pm 0.14^{\mathrm{Ca}}$ & $1.38 \pm 0.26^{\mathrm{Da}}$ \\
\hline $\mathrm{T}$ & $0.67 \pm 0.06^{\mathrm{Aa}}$ & $0.57 \pm 0.15^{\mathrm{Aa}}$ & $0.60 \pm 0.24$ & $0.42 \pm 0.15^{\mathrm{Aa}}$ \\
\hline $\mathrm{U}$ & $0.72 \pm 0.20^{\mathrm{Aab}}$ & $0.58 \pm 0.10^{\mathrm{Aa}}$ & $0.93 \pm 0.08^{\mathrm{Bb}}$ & $0.75 \pm 0.19^{\mathrm{Bab}}$ \\
\hline NT & $0.60 \pm 0.16^{\mathrm{Aa}}$ & $0.49 \pm 0.10^{\mathrm{Aa}}$ & $0.47 \pm 0.06^{\mathrm{Aa}}$ & $1.52 \pm 0.21 \mathrm{Db}$ \\
\hline K & $1.48 \pm 0.20^{\mathrm{Bb}}$ & $1.01 \pm 0.11^{\mathrm{Ba}}$ & $0.91 \pm 0.12^{\mathrm{Ba}}$ & $1.02 \pm 0.08^{\mathrm{Ca}}$ \\
\hline L-L & $1.61 \pm 0.32^{\mathrm{Ba}}$ & $1.48 \pm 0.44^{\mathrm{Ca}}$ & $1.54 \pm 0.18^{\mathrm{Ca}}$ & $1.46 \pm 0.32^{\mathrm{Da}}$ \\
\hline L-T & $5.83 \pm 2.17 \mathrm{Ca}$ & $6.08 \pm 1.04 \mathrm{Ea}$ & $5.29 \pm 2.69 \mathrm{Da}$ & $5.97 \pm 1.24 \mathrm{Fa}$ \\
\hline L-U & $0.65 \pm 0.18^{\mathrm{Aa}}$ & $0.71 \pm 0.23^{\mathrm{ABa}}$ & $0.91 \pm 0.19^{\mathrm{Ba}}$ & $0.83 \pm 0.16^{\mathrm{BCa}}$ \\
\hline L-NT & $7.70 \pm 1.88^{\mathrm{Cb}}$ & $6.65 \pm 2.01 \mathrm{~Eb}$ & $7.92 \pm 1.95^{\mathrm{Db}}$ & $3.17 \pm 2.38^{\mathrm{Ea}}$ \\
\hline $\mathrm{L}-\mathrm{K}$ & $7.21 \pm 3.16^{\mathrm{Cb}}$ & $3.23 \pm 2.63^{\mathrm{Da}}$ & $7.55 \pm 2.95^{\mathrm{Db}}$ & $5.54 \pm 3.72^{\mathrm{Fab}}$ \\
\hline
\end{tabular}

Horizontally, identical superscripted lowercase letters denote no significant differences among groups ( $p>0.05$ ). Vertically, identical superscripted uppercase letters denote no significant differences among materials $(\mathrm{p}>0.05)$.
For comparison purposes, bulk specimens of all materials were prepared to the thickness of the relined specimens $(4 \mathrm{~mm})$ and tested. The bulk and relined specimens were then divided into 1 control and 3 test groups. For K, NT, T and U reline resins, control (C) specimens (bulk and relined) were subjected to the impact tests within 30 min after polymerization, whereas L control specimens (bulk and relined with the same material) were stored in distilled water at 37 $\pm 1^{\circ} \mathrm{C}$ for $50 \pm 2 \mathrm{~h}$ before the impact testing (17). For the 3 test groups, the impact tests were performed after the specimens were immersed in distilled water at 37 $\pm 1^{\circ} \mathrm{C}$ for 7 days (Wim7d), 90 days (Wim90d) and 180 days (Wim180d), respectively. For each group, 10 to 18 specimens were prepared and tested.

Before testing, specimens were notched with a notching cutter (Notchvis; Ceast, Pianezza, Italy). The V-notches were cut into the reline materials, across the width of specimens with $0.8 \mathrm{~mm}$ depth leaving an effective depth under the 3.2 $\mathrm{mm}$ notch (7). The ISs were evaluated by the Charpy impact tester (Resil 25R; Ceast), with the unnotched surface of the specimens facing the pendulum. The test was performed with 0.5 $\mathrm{J}$ pendulum and $150^{\circ}$ lifting angle. IS, expressed in $\mathrm{kJ} / \mathrm{m}^{2}$, was calculated as IS $=\mathrm{E}_{\mathrm{C}} / \mathrm{h}$ $\left.b_{A}\right)$, where $E_{C}$ is the corrected energy absorbed by breaking the test specimen, $b_{A}$ is the remaining thickness at the notch tip, and $h$ is the specimen width.

Two-way ANOVA and Tukey Honestly Significant Difference (HSD) post-hoc test, at a $95 \%$ confidence level, were used for analysis of data.

\section{RESULTS}

Table 2 shows the mean IS values and the standard deviations for all conditions evaluated. U specimens 
immersed in water for 90 days (Wim90d) showed significantly higher $(\mathrm{p}=0.006)$ mean values than those immersed in water for 7 days (Wim7d). After 180 days of water immersion (Wim180d), NT specimens exhibited significantly higher mean values compared to the other groups $(\mathrm{p}=0.000)$. $\mathrm{K}$ specimens showed a significant reduction in the IS after 7 days of water immersion $(p=0.000)$, and then remained unaffected. For materials $\mathrm{L}$ and $\mathrm{T}$, no significant differences were found among all groups.

The results for the relined specimens showed that, after 180 days of water immersion, the IS of L-NT specimens was significantly lower $(p=0.000)$ in comparison to the other groups. L-K specimens showed a significant decrease in the IS from control to 7 days of water immersion $(\mathrm{p}=0.000$ ). However, no significant difference was found between groups Wim90d and Wim180d, which in turn were not significantly different from the control group. When L denture base resin was relined using the same material (L-L) or the autopolymerizing reline resins $\mathrm{T}$ and $\mathrm{U}$, there were no significant differences among the groups.

For control specimens, the ISs of L and $\mathrm{K}$ resins did not differ significantly, and both were higher $(p=0.000)$ than those of T, U and NT. There was no significant difference between L bulk and L-L specimens. L-U specimens showed significantly lower $(\mathrm{p}=0.000)$ mean IS compared to L bulk specimens. The highest IS values were seen for L-T, L-NT and L-K $(\mathrm{p}=0.000)$.

When Wim180d bulk specimens were compared, the results can be arranged as $\mathrm{L}=\mathrm{NT}>\mathrm{K}>\mathrm{U}>\mathrm{T}$. No significant difference was found between $\mathrm{L}$ and $\mathrm{L}-\mathrm{L}$ specimens. L-T and L-K promoted the highest mean IS values, which differed significantly from L-NT ( $\mathrm{p}=0.002$, $\mathrm{p}=0.018$, respectively). The lowest IS was found for $\mathrm{L}-\mathrm{U}$ specimens $(\mathrm{p}=0.000)$.

\section{DISCUSSION}

The Charpy type test selected for the present study have been used by investigators to evaluate the IS of denture base acrylic resins $(1,3,4,7)$. The work hypothesis that water storage would not have a significant effect on the IS of the denture base resin and the reline materials was rejected in part. For U, the specimens immersed in water for 90 days showed significantly higher IS than those immersed for 7 days. NT exhibited a significant increase in the IS after 180 days of water immersion. Conversely, $\mathrm{K}$ reline resin exhibited a significant decrease in the IS after 7 days of water immersion and then stabilized. Takahashi et al. (12) also observed that the effect of water immersion on the flexural strength of denture base and reline resins varied among materials. They attributed the results to the fact that the mechanical strength of water-sorbed acrylic resins depends on the intrinsic strength of the resin and the amount of water absorbed in the system. Because water molecules are smaller than the interchain distance in the resins, they can be absorbed into the material, decreasing the secondary chemical bonding forces between these chains (19). As a result, the mechanical properties of the polymer are lowered. The addition of cross-linking agents decreases the amount of water absorbed by reline resins during soaking (8). Given that $\mathrm{K}$ does not contain cross-linking agent, it can be supposed that the decrease in the IS after water immersion for 7 days may be due to the plastizicing effect of water, which may be different in each resin, changing the stiffness of the material. Although NT is also a non-cross linked reline resin, it contains the plasticizer di-n-butyl phthalate, which has been shown to reduce water sorption (8). Plasticizer molecules can fill microvoids and thereby exclude water uptake (8). For U, the manufacturer states that this material contains high percentage of the cross-linking agent 1,6-hexanediol dimethacrylate, which may have reduced the water uptake. The increase in the IS of U and NT observed at the 90-day and 180-day immersion periods, respectively, may be explained by the competing effects of post-polymerization and residual monomer release of the materials and gradual water sorption (10). It is likely that the further polymerization and residual monomer release mechanisms overcame the plasticizing effect of the water uptake.

Water immersion did not significantly affect the IS of the materials $\mathrm{L}$ and T. Similar results were found for the specimens relined using $\mathrm{L}, \mathrm{T}$ and $\mathrm{U}$. These findings were probably due to the presence of the cross-linking agents ethylene glycol dymethacrylate, 1,9 nonanediol dimethacrylate and 1,6-hexanediol dymethacrylate in the liquids of these materials. For the specimens relined using $\mathrm{K}$, there was a significant decrease in the IS after 7 days of water immersion. The reduction in the IS observed for K bulk specimens, for the same period of immersion, may have accounted for this finding. The IS of a relined specimen is a function of the inherent strength of denture base and reline material and the plasticizing effect of water (12), which may be different in each resin. 
Thus, it can be supposed that the decrease in the IS of the material $\mathrm{K}$, after 7 days of storage in water, may have decreased the strength of the relined $\mathrm{L} / \mathrm{K}$ specimens. Differently from the NT bulk specimens, which showed significantly higher IS after 180 days of immersion in water, the L specimens relined using NT exhibited a significant decrease at the same immersion time. Thus, the inherent strength of the reline resin NT alone cannot explain the results, suggesting that other factors may be involved and should be further investigated.

When bulk specimens of control group were compared, the IS of the denture base acrylic resin L was higher than the reline resins, with the exception of material $\mathrm{K}$. The lower IS of $\mathrm{T}$ and $\mathrm{U}$ could be related to their higher concentration of cross-linking agents. An increase in the cross-linking reaction has been reported to decrease the flowability of polymer, which resulted in a reduction of the IS (7). Therefore, it can be supposed that during the polymerization reaction of $\mathrm{T}$ and $\mathrm{U}$ materials, a highly cross-linked polymer network is formed, which reduces their IS. The lower IS of NT bulk specimens could be attributed to the plasticizer contained in the liquid. In general, at a higher plasticizer concentration (more than 15-20\%), the materials become softer and tougher, with lower tensile strength, and higher IS (11). It is likely that the low plasticizer concentration (8\%) (8) may have accounted for the low IS of NT. K bulk specimens showed significantly higher IS than the other reline resins evaluated. This could be related to its higher residual monomer content (9), since an increase in the residual monomer improves the IS of autopolymerized acrylic resins (2).

For control group, comparison between bulk and relined specimens revealed that the IS of the resin $\mathrm{L}$ was maintained when the relining was made with the same material. In addition, the specimens relined using L showed no significant differences from 1 day to 180 days of immersion in water. Given that the cracks in L-L specimens always propagated through the same material, the energy required for the crack initiation and propagation was probably similar in the $\mathrm{L}$ and $\mathrm{L} / \mathrm{L}$ specimens. Another factor that should be considered is the influence of the interface on a crack penetrating that interface from one material into the second one in a bi-material laminate. For the $\mathrm{L} / \mathrm{L}$ specimens, the chemical similarity between the denture base and reline materials (15), the time during which the material remained in the doughy state under pressure (30 min) and the polymerization cycle with a terminal boil may have contributed to the formation of an interpenetrating network and a diffuse interface (13). As a result, the cracks may have propagated in the $\mathrm{L} / \mathrm{L}$ relined specimens as if they propagated in the L bulk specimens. The results obtained in the present investigation are comparable to those of Jagger et al. (6), who found that the IS of a heatpolymerizing acrylic resin $\left(1.62 \mathrm{~kJ} / \mathrm{m}^{2}\right)$ did not change after 6 months of storage in water at $37^{\circ} \mathrm{C}\left(1.58 \mathrm{~kJ} / \mathrm{m}^{2}\right)$.

Results from control and Wim180d groups revealed that the IS of the specimens relined with $U$ was significantly lower than those of L specimens, either intact or relined with the same material. These findings could be related to the low IS of U. The bond between this reline resin and L may also have contributed to these findings. The bonding agent of $U$ is composed of dichloromethane and 2-hydroxyethyl methacrylate (HEMA). Dichloromethane improves the reline material capacity to combine with the denture base swollen layers (14). HEMA monomer has a solubility parameter close to that of poly(methyl methacrylate) and a lowmolecular-weight, thus facilitating its diffusion into the denture base resin (20). These may have resulted in a strong bond between $\mathrm{U}$ and $\mathrm{L}$, allowing the cracks to propagate from the reline resin into the denture base resin without crack deflection at the interface.

Relining with T, NT and K materials promoted the highest ISs in all groups, and delamination between the denture base and reline resin was observed for the majority of the samples. These findings could be related to the differences in the ability of the bonding agents to dissolve and penetrate the swollen denture base surface. While $U$ bonding agent contains both a solvent and a monomer, $\mathrm{T}$ bonding agent contains only nonpolymerizable solvents (ethyl acetate and acetone). For material NT, the bonding agent contains methyl methacrylate (8), which was also used for wetting the bonding surfaces when $\mathrm{K}$ reline resin was used (18). Hence, it can be supposed that the delamination between the reline and the denture base resins may have consumed energy during the tests, thus increasing the IS of the relined specimens. It should be noted that when $\mathrm{L}$ specimens were relined with T, NT and K materials, the standard deviations were high. Hence, although relining with these materials promoted improved IS than relining with the denture base resin $\mathrm{L}$, the outcomes are less predictable.

This study has limitations and the results should be interpreted with caution. Although the specimens were immersed in water at $37^{\circ} \mathrm{C}$ to simulate the clinical 
situation, in the adverse oral environment conditions, the materials are also submitted to thermal and loading stresses, and these aspects should be considered in future studies. Nevertheless, results demonstrated that the IS of the acrylic resins used for the construction and relining denture bases may be affected differently by water. Results also suggested that adhesion between the denture base and reline materials at their interface may be an important factor influencing the resistance to fracture of relined denture bases.

\section{RESUMO}

A água pode influenciar as propriedades mecânicas das resinas acrílicas. Assim, o efeito do armazenamento em água na resistência ao impacto (RI) de uma resina para base de prótese (Lucitone 550-L) e quatro materiais reembasadores (Tokuyama Rebase II-T; UfiGel Hard-U; Kooliner-K; New Truliner-NT) foi avaliado. Barras da resina $L$ foram confeccionadas $(60 \times 6 \times 2$ $\mathrm{mm}$ ) e reembasadas ( $2 \mathrm{~mm}$ ) com T, U, K, NT e L. Amostras não reembasadas de cada material também foram confeccionadas $(60 \times 6 \times 4 \mathrm{~mm})$ para fins comparativos. As amostras foram submetidas aos testes de impacto tipo Charpy sem armazenamento (controle) e após imersão em água por 7, 90 e 180 dias. Os resultados $\left(\mathrm{kJ} / \mathrm{m}^{2}\right)$ analisados por meio de ANOVA dois fatores e teste de Tukey $(\mathrm{p}=0,05)$ revelaram que, após 90 dias, $\mathrm{U}$ exibiu aumento na RI $(0,93)$ comparado com 7 dias $(0,58)$. K $(1,48)$ e $\mathrm{L} / \mathrm{K}(7,21)$ exibiram diminuição no período de 7 dias $(1,01$ e 3,23, respectivamente). NT $(0,60)$ apresentou aumento na RI após 180 dias $(1,52)$, enquanto L/NT $(7,70)$ apresentou redução $(3,17)$. A imersão em água melhorou a RI de U e NT e diminuiu a RI de $\mathrm{K}, \mathrm{L} / \mathrm{K}$, e L/NT. A água pode afetar de maneira diversa a RI das resinas acrílicas e, consequentemente, a resistência à fratura das bases de próteses reembasadas.

\section{ACKNOWLEDGEMENTS}

This investigation was supported by the Brazilian Council for Scientific and Technological Development (CNPq - Grant 301042/2004-7) and The São Paulo State Research Foundation (FAPESP - Grant 06/01044-8).

\section{REFERENCES}

1. Doğan OM, Bolayir G, Keskin S, Doğan A, Bek B, Boztuğ A. The effect of esthetic fibers on impact resistance of a conventional heat-cured denture base resin. Dent Mat J 2007;26:232-239.

2. Oku J. Impact properties of acrylic denture base resin. Part 2. Effect of temperature and residual monomer on impact characteristics. Dent Mat J 1989;8:186-193.

3. Memon MS, Yunus N, Razak AA. Some mechanical properties of a highly cross-linked, microwave-polymerized, injection-molded denture base polymer. Int J Prosthodont 2001;14:214-218.
4. Straioto FG, Ricomini Filho AP, Fernandes Neto AJ, Del Bel Cury AA. Polytetrafluorethylene added to acrylic resins: mechanical properties. Braz Dent J 2010;21:55-59.

5. Consani RL, Azevedo DD, Mesquita MF, Mendes WB, Saquy PC. Effect of repeated disinfections by microwave energy on the physical and mechanical properties of denture base acrylic resins. Braz Dent J 2009;20:132-137.

6. Jagger DC, Harrison A, al-Marzoug K. Effect of the addition of poly(methyl methacrylate) beads on some properties of acrylic resin. Int J Prosthodont 2000;13:378-382.

7. da Cruz Perez LE, Machado AL, Canevarolo SV, Vergani CE, Giampaolo ET, Pavarina AC. Effect of reline material and denture base surface treatment on the impact strength of a denture base acrylic resin. Gerodontology 2010;27:62-69.

8. Arima T, Murata H, Hamada T. Properties of highly crosslinked autopolymerizing reline acrylic resins. J Prosthet Dent 1995;73:55-59.

9. Urban VM, Machado AL, Oliveira RV, Vergani CE, Pavarina AC, Cass QB. Residual monomer of reline acrylic resins. Effect of water-bath and microwave post-polymerization treatments. Dent Mat 2007;23:363-368.

10. Lamb DJ, Ellis B, Priestley D. The effects of process variables on levels of residual monomer in autopolymerizing dental acrylic resin. J Dent 1983;11:80-88.

11. Matuana LM, Park CB, Balatinecz JJ. The effect of low levels of plasticizer on the rheological and mechanical properties of polyvinyl choride/newsprint-fiber composites. J Vinyl Addit Technol 1997;3:265-273.

12. Takahashi Y, Chai J, Kawaguchi M. Effect of water sorption on the resistance to plastic deformation of a denture base material relined with four different denture reline materials. Int J Prosthodont 1998;11:49-54

13. Vallittu PK, Ruyter IE, Nat R. The swelling phenomenon of acrylic resin polymer teeth at the interface with denture base polymers. J Prosthet Dent 1997;78:194-199.

14. Mutluay MM, Ruyter IE. Evaluation of adhesion of chairside hard relining materials to denture base polymers. J Prosthet Dent 2005;94:445-452.

15. Arena CA, Evans DB, Hilton TJ. A comparison of bond strengths among chairside hard reline materials. J Prosthet Dent 1993;70:126-131.

16. Aydin AK, Terzioğlu H, Akinay AE, Ulubayram K, Hasirci N. Bond strength and failure analysis of lining materials to denture resin. Dent Mat 1999;15:211-218.

17. International Standards Organization. ISO 1567:1999/Amd 1: 2003. Dentistry-denture base polymers. Amendment. Available at: http://www.iso.ch/iso/en/prods-services/ ISOstore/store.html. Accessed on May 8, 2009.

18. Leles CR, Machado AL, Vergani CE, Giampaolo ET, Pavarina AC. Bonding strength between a hard chairside reline resin and a denture base material as influenced by surface treatment. J Oral Rehabil 2001;28:1153-1157.

19. Rantala LI, Lastumäki TM, Peltomäki T, Vallittu PK. Fatigue resistance of removable orthodontic appliance reinforced with glass fibre weave. J Oral Rehabil 2003;30:501-506.

20. Tezvergil A, Lassila LV, Vallittu PK. The shear bond strength of bidirectional and random-oriented fibre-reinforced composite to tooth structure. J Dent 2005;33:509-516.

Accepted December 21, 2010 